\title{
REVIEW
}

\section{Delegation of Power and Institutional Competence}

\author{
James O. Freedman $\dagger$
}

The first sentence of the Constitution, after the Preamble, provides: "All legislative Powers herein granted shall be vested in a Congress of the United States . . . ." From the beginning of the Republic, Congress has regularly chosen to delegate portions of that power to others, primarily the administrative agencies it has created and the President. The Supreme Court has almost always sustained the constitutionality of such delegations, ${ }^{2}$ while at the same time asserting the continuing vitality of earlier pronouncements of an apparently contradictory character, such as the familiar statement from Field v. Clark: "That Congress cannot delegate legislative power to the President is a principle universally recognized as vital to the integrity and maintenance of the system of government ordained by the Constitution." 3 In this respect the Court has behaved much like Byron's Julia who, as Justice Jackson once recalled, "whispering 'I will ne'er consent,'-consented."

Because the results the Court has reached have often seemed inconsistent with the principles it has stated in reaching them, the non-delegation doctrine has long been regarded as theoretically unsatisfactory. ${ }^{5}$ And since, as a practical matter, the Court has generally sustained even the broadest transfers of legislative power, ${ }^{6}$ some

$\dagger$ Professor of Law and University Ombudsman, University of Pennsylvania.

U.S. ConsT. art. I, $\S 1$.

2 The two most notable exceptions are A.L.A. Schechter Poultry Corp. v. United States, 295 U.S. 495 (1935), and Panama Ref. Co. v. Ryan, 293 U.S. 388 (1935). In Schechter, the Court held unlawful the delegation of power to the President to develop and approve "codes of fair competition" that included regulation of minimum wages, maximum hours, and competitive practices, because the delegation permitted the President to exercise an "unfettered" discretion. 295 U.S. at 542. In Panama Refining, the Court invalidated the narrower delegation to the President of the power to prohibit the interstate shipment of oil produced in contravention of state laws. See also Carter v. Carter Coal Co., 298 U.S. 238 (1936), which held unlawful Congress's delegation to private parties of authority to fix maximum hours and minimum wages, discussed in text at notes 130-33 infra.

3143 U.S. 649, 692 (1892). In United States v. Shreveport Grain \& Elevator Co., 287 U.S. 77,85 (1932), the Court, in upholding the delegation at issue, said: "That the legislative power of Congress cannot be delegated is, of course, clear." See also $1 \mathrm{~T}$. COoley, Constitutional Limitations 244 (8th ed. 1927).

- Everson v. Board of Educ., 330 U.S. 1, 19 (1947) (dissenting opinion).

5 The most important judicial attempt in recent years to rationalize the doctrine is Judge Leventhal's opinion in Amalgamated Meat Cutters \& Butcher Workers v. Connally, 337 F. Supp. 737 (D.D.C. 1971); see B. SchwarTZ, Administrative Law § 18, at 45 (1976).

- One limitation on the breadth of legislative delegation often adverted to by the Court 
commentators have criticized the Court for permitting greater delegations of legislative authority than is wise for effective governance, ${ }^{7}$ thereby contributing to "the atrophy of institutions of popular control."8 Others have characterized the doctrine as "almost a complete failure" in preventing the effective delegation of legislative power. ${ }^{9}$ Still others believe that the Supreme Court's permissive interpretation of the doctrine, by permitting Congress to withhold from administrative agencies a clear mandate to achieve national policies, has invited encroachments upon agency independence, ${ }^{10}$ thereby contributing significantly to recurring public perceptions of a crisis in the administrative process."

The question of whether and upon what conditions Congress should be permitted to delegate legislative power to other institutions is central to the theory of democratic government as well as to the effective performance of administrative agencies. The Constitution does not speak to the question explicitly, perhaps because the Framers did not consider the question a serious one. Apparently the only reference to legislative delegation in the records of the Constitutional Convention is Madison's motion that the President be given power "to execute such other powers . . . as may from time to time be delegated by the national legislature." The motion was defeated as unnecessary. ${ }^{12}$

is that "Congress cannot delegate any part of its legislative power except under the limitation of a prescribed standard." United States v. Chicago, M., St. P. \& P.R.R., 282 U.S. 311, 324 (1931). But in practice the requirement of a prescribed standard has proven so expansive that it has had little inhibiting effect. See, e.g., FCC v. Pottsville Broadcasting Co., 309 U.S. 134 (1940) ("public convenience, interest or necessity" is adequate standard); FTC v. Gratz, 253 U.S. 421 (1920) ("unfair methods of competition" is adequate standard).

3 T. Lowi, The End of Liberalism 145 (1969).

' Lowi, The Public Philosophy: Interest-Group Liberalism, 61 AM. PoL. Scr. Rev. 5, 18 (1967); T. Lowi; supra note 7, at 125-36; see Jaffe, The Illusion of the Ideal Administration, 86 Harv. L. Rev. 1183 (1973); Wright, Beyond Discretionary Justice, 81 YaLe L.J. 575 (1972).

- K. Davis, Administrative Law Treatise $\S 2.00$, at 40 (Supp. 1970); Davis, A New Approach to Delegation, 36 U. CHI. L. Rev. 713 (1969); see note 59 infra. A British commentator has written that the requirement of a standard has become "hardly more than a ceremonial incantation handed down from an earlier constitutional era." Wade, Anglo-American Administrative Law: Some Reflections, 81 LAw. Q. REv. 357, 372 (1965); see B. SchwarTz \& H. Wade, Legal Control of Government: Administrative Law in Britain and the United STATES 31-32 (1972).

$10 \mathrm{H}$. Friendly, The Federal Administrative Agencies: The Need for Better Definition of Standards 6, 22-23 (1962); L. Jaffe, Judicial Control of Administrative Action 48-51 (1965).

"Freedman, Crisis and Legitimacy in the Administrative Process, 27 Stan. L. Rev. 1041 (1975); Stewart, The Reformation of American Administrative Law, 88 HaRv. L. REv. 1669, 1693-97 (1975).

121 The Records of the Federal Convention of 1787, at 67 (M. Farrand ed. 1911). The only reference to delegation in The Federalist relates to the President's pardoning power. THE 
The failure of the Constitutional Convention to devote any further attention to the delegation of legislative power may be explained by the Framers' belief that the legislature would be more likely to aggrandize than to delegate its powers; Madison and his contemporaries chiefly feared "legislative usurpations."13 As Madison was to write in The Federalist, "[the] legislative department is everywhere extending the sphere of its activity, and drawing all power into its impetuous vortex."14 Holding such fears, the Framers may not have regarded the prospect of voluntary legislative divestments of power as particularly worrisome.

Although the Constitution does not explicitly prohibit the delegation of legislative power, neither does it explicitly authorize it. The language most frequently relied upon to support the constitutionality of delegation is the "necessary and proper" clause-the power of Congress "to make all Laws which shall be necessary and proper for carrying into Execution the foregoing powers, and all other Powers vested by this Constitution in the Government of the United States, or in any Department or Officer thereof." 15 This language does not, of course, explicitly support the constitutionality of delegation. But whatever the silences of the constitutional language, the propriety of delegating legislative power must now be regarded as having been settled by the practice of two centuries.

Since delegation of legislative power is permissible in some degree, the important question is in what circumstances and upon what conditions Congress should be permitted to delegate. Although the theoretical basis of the traditional non-delegation doctrine has been eroded by the Court's inconstant practice, the philosophical and institutional issues raised by the delegation of legislative power remain of great contemporary significance. Professor Sotirios A. Barber, a political scientist, now joins a line of eminent commentators ${ }^{16}$ in addressing these issues. ${ }^{17} \mathrm{He}$ seeks to "develop a general

Federalist No. 74, at 473-75 (B. Wright ed. 1961) (A. Hamilton).

13 The Federalist No. 48, at 344 (B. Wright ed. 1961) (J. Madison); see The Federalist No. 73, at 468-69 (B. Wright ed. 1961) (A. Hamilton) (discussing the "propensity of the legislative department to intrude upon the rights, and to absorb the powers, of the other departments").

11 The Federalist No. 48, at 343 (B. Wright ed. 1961) (J. Madison).

15 U.S. Const. art. I, \& 8; see McCulloch v. Maryland, 17 U.S. (4 Wheat.) 316 (1819).

1 J. Landis, The Administrative Process 47-88 (1938); T. Lowi, supra note 7, at 125-56 (1969); Cheadle, The Delegation of Legislative Functions, 27 YALE L.J. 892 (1918); Davis, supra note 9; Jaffe, An Essay on Delegation of Legislative Power (pts. 1-2), 47 Colum. L. REv. 359,561 (1947).

17 S. Barber, The Constitution and the Delegation of Congressional Power (1975) [hereinafter cited as BARBER]. 
legal theory of what the rule ought to mean for the practice of Congress"18 and to recommend a set of criteria by which to judge the constitutionality of specific delegations. His mission is to determine the constitutional foundation and scope of the non-delegation doctrine. He seeks to ascertain the "minimal limitations on the power to delegate [that] are reasonably implicit in the Constitution itself." 19

\section{Professor Barber's Analysis}

Although the courts have traditionally regarded the rule against the delegation of legislative power as constitutionally derived, its specific source in the Constitution has never been conclusively established. Because the language of the Constitution does not speak explicitly to the question of delegation, it is not surprising that scholars have sought constitutional foundation for the nondelegation doctrine in a variety of principles, with some doubting that the rule has any proper constitutional status at all. ${ }^{20}$

Cognizant of this long-standing debate, Professor Barber begins his analysis by seeking to establish that the rule against the delegation of legislative power is "implicit in principles whose authority in constitutional theory is beyond question," 21 rather than being rooted in any of the more specific principles usually cited in support of the rule, such as the separation of powers, the common law maxim of delegata potestas non potest delegari, ${ }^{22}$ due process, or the principle of government by representative assembly. Professor Barber's argument, briefly put, is that the concept of constitutional supremacy logically provides the best theoretical foundation for the rule of non-delegation ${ }^{23}$ and that "a prohibition against those delegations which amount to abdications of power is a corollary of the idea of constitutional supremacy to be found in the expectations of people who organize institutions and vest them with powers of government."'24

18 Id. at 1.

10 Id. at 6.

20 C. Friedrich, Constitutional Government and Democracy 580 (1960); R. Tresolini, American Constitutional Law 154-58 (1965); Roche, Distribution of Powers, 3 Int'l Encyc. Soc. Scr. 305-07 (D. Sills ed. 1968). See also C. Swisher, American Constitutional Development 910 (1954); Duff \& Whiteside, Delegata Potestas Non Potest Delegari: A Maxim of American Constitutional Law, 14 CoRnelL L.Q. 168 (1929).

21 BARBER, supra note 17 , at 12.

${ }^{22}$ A power that is originally delegated may not be redelegated.

${ }^{23}$ BARBER, supra note 17, at 13.

24 Id. at 12. 


\section{A. The Principle of Constitutional Supremacy}

Professor Barber believes that "the Constitution has its genesis in a practical political proposal as a set of means for achieving certain desired ends," most of which are expressed "on a rather high level of generalization." 25 Disagreement over the appropriate institutional means to achieve the Constitution's ends has dominated constitutional debate in American history to such an extent that "disputes over institutional forms and relationships have frequently suggested that the institutional means to the ends of government are valued as ends in themselves." 26

As important as this "instrumental facet" of the Constitution may be, "the fact that the document was ordained and established as the 'supreme law of the land' indicates that it cannot be adequately conceptualized as a mere set of means." 27 Rules that are merely means to an end, Professor Barber argues, retain authority only insofar as the end remains desirable. ${ }^{28}$ But the Constitution has an authority independent of any particular desired end; it is "law to be obeyed no matter what we feel about the ends it may serve or its utility in achieving them." 29 The Constitution, in short, was designed to bind future generations "to certain ways of doing the business of government." 30

The Framers of the Constitution must be understood, then, to have removed "certain institutional alternatives from the sphere of legally uninhibited choice" in order to ensure that "the binding character of the constitutional arrangement of offices and powers" would be forever maintained..$^{31}$ From that understanding Professor Barber derives his major premise: ${ }^{32}$

${ }^{25}$ Id. at 13.

26 Id. at 13-14.

${ }^{27}$ Id. at 14.

${ }^{23}$ As Professor Barber argues:

Rules possessing only instrumental qualities are dependent for their authority solely on the values and perceptions of those to whom they are recommended. Such rules would not be rules of law. If there is no other reason to obey a rule than the desirable things it purports to achieve, then one is free to ignore the rule if one decides either that he does not want what the rule purports to bring about or that the desired result cannot actually Id.

be reached through the rule.

Id.

oId.

31 Id. at 16.

${ }^{32}$ Id. at 17. In developing this theme, Professor Barber draws upon John Locke's wellknown argument, made in 1690, that a "legislature cannot transfer the power of making laws to any other hands; for it being but a delegated power from the people, they who have it cannot pass it over to others." J. Locke, Second Treatise on Crvil Government § 141, at 8384 (E. Barker ed. 1967); BARBER, supra note 17, at 25. 
[D]elegations of the most extreme kinds would defeat the desire to maintain the constitutional arrangement of offices and powers. This is so because abdication would be one of the ways of destroying the constitutional arrangement. If the desire to maintain the constitutional arrangement of offices and powers is expressed in the concept of constitutional supremacy, then the concept of constitutional supremacy can provide us with the origin of that application of the nondelegation doctrine which would prevent the abdication of constitutionally imposed duties. Why not abdication? Because abdication would result in a new arrangement of offices and powers. Why not a new arrangement? Because the old arrangement was established as supreme law by what is thought to be authority superior to all other legal authority.

From this premise Professor Barber concludes that a rule proscribing such extreme delegations of legislative authority as can properly be adjudged abdications of power is "grounded in a concept of unquestionable constitutional status, the concept of constitutional supremacy." "33

Having designated the concept of constitutional supremacy as the true foundation for the rule against delegation of legislative power, Professor Barber undertakes to distinguish a number of other principles that historically have been associated with the nondelegation rule.

The concept of the separation of powers is the one most frequently associated with the non-delegation doctrine. ${ }^{34}$ But Professor Barber is skeptical of the association. The fact that the Constitution separates powers and characterizes them as legislative, executive, and judicial does not, in his view, support the implication that those powers must remain forever separated. ${ }^{35} \mathrm{He}$ argues that the general principle of constitutional supremacy-that "the powers of government are delegated by the people in an arrangement binding on the government"-is more fundamental to the constitutional scheme than the particular arrangement by which powers are separated and specified. It thus provides a more satisfying explanation for the rule of non-delegation. When the rule of non-delegation applies, in Professor Barber's analysis, it is "because the power in question is

33 Id. at 18.

34 See, e.g., R. Cushman, The Independent Regulatory Commissions 427 (1941) (the concept of non-delegation is a "corollary of the doctrine of the separation of powers").

3s BARBER, supra note 17 , at 24 . 
granted-not because it is either legislative or separated." 36

A second principle frequently cited as supporting the rule of non-delegation is the common law maxim of delegata potestas non potest delegari-a power that is originally delegated may not be redelegated..$^{37}$ Professor Barber regards this maxim as a more useful device than the separation of powers for understanding the basis of the non-delegation rule because it focuses upon "expectations in the act of granting power," ${ }^{38}$ rather than upon the particular manner in which power is allocated. But he concludes that the rule of nondelegation cannot ultimately be grounded in the maxim because its roots in the common law tend to encourage the view that the nondelegation rule is "entirely judge-made law" and "in some sense an import from the law of agency, and not fully authoritative on that account." ${ }^{39} \mathrm{He}$ therefore finds this view unacceptable because it obscures the fact that the rule against delegation is a principle of constitutional law.

Some scholars have argued that the non-delegation doctrine finds its proper source in still a third principle, the constitutional guarantee of due process of law. ${ }^{40}$ Those who embrace this view argue that the purposes of the non-delegation doctrine and of the due process clause are essentially similar. The non-delegation doctrine, by confining "the exercise of broad and untrammeled legislative discretion in a representative legislature," ${ }^{41}$ seeks to prevent the transfer of this power to an officer or agency without the restraining influence of legislative standards. It thereby protects the substantive rights of the individual from arbitrary administrative invasion-precisely a mission that the due process clause would undertake in the absence of the rule of non-delegation.

Professor Barber regards the argument as deficient in two respects. First, the rule of non-delegation and the due process clause serve a similar function only if one believes that the legislature alone is capable of making rules to protect individual rights. Yet the failure of the legislature to protect the individual by providing a delegate with meaningful statutory standards, as the non-delegation

36 Id. at 25 (emphasis in original).

${ }^{31}$ See, e.g., Duff \& Whiteside, supra note 20. See also Ehmke, "Delegata Potestas Non Potest Delegari," A Maxim of American Constitutional Law, 47 CoRnel. L.Q. 50 (1961).

38 BarBer, supra note 17, at 27.

30 Id. at 27. See also L. JAFFE, supra note 10, at 54.

to See, e.g., Cushman, The Constitutional Status of the Independent Regulatory Commissions, 24 CORNELl L.Q. 13, 32-33 (1938). See also McGowen, An Economic Interpretation of the Doctrine of Delegation of Governmental Powers, 12 Tul. L. REv. 179 (1938).

1" Barber, supra note 17 , at 31 , quoting Cushman, supra note 40 , at 32 . 
doctrine has traditionally required it to do, need not result in arbitrary administrative action. Administrators themselves can formulate specific rules that are "at least as good, qua rules, as those drafted by legislators." 42 Second, to view the rule of non-delegation as merely an application of the due process clause, on the ground that both seek to confine discretion in order to protect substantive constitutional rights, would mean that "no delegation could be unconstitutional, however extreme, in the absence of injury to protected rights." ${ }_{43}$ This view not only narrows the traditional role of the non-delegation doctrine, but also assumes, once again, that Congress alone is capable of protecting the rights of the individual.

Finally, Professor Barber contends that attempts to assimilate the non-delegation rule to the due process clause actually represent an effort to explain the rule of non-delegation in terms of a fourth principle-that in a democratic society "only a 'representative legislature' can be entrusted with untrammeled discretion to make rules governing individual conduct and affecting individual rights." 44

As attractive as this final principle may appear, Professor Barber finds it inadequate to support and define the rule of nondelegation. Acceptance of this principle, he argues, would theoretically permit delegations of legislative power whenever the values of representation would be served better by institutions other than the legislature, whether they be federal administrative agencies, state governments, state administrative agencies, private groups, or even electoral constituencies. ${ }^{45}$ Delegations of this character would be acceptable to some theories of democractic representation but not, of course, to others ${ }^{46}$ For Professor Barber, the principle of government by representative assemblies is compatible with the rule of non-delegation only when an independent principle requires that the original system of representation be regarded as legally binding without respect to whether another institution might better serve the values of representation in a particular case. ${ }^{47}$

Professor Barber's tour d'horizon of the separation of powers, the common law maxim prohibiting delegation, the due process

\footnotetext{
12 Barber, supra note 17 , at 32 (emphasis in original); see $\mathrm{K}$. Davis, Discretionary Justice: A Preliminary Inquiry 52-61 (1969); K. Davis, Police Discretion 98-138 (1975).

13 Barker, supra note 17 , at 33 .

"Id. at 34; see 1 T. Cooley, Constitutional Limitations 224 (8th ed. 1927); L. JafFe, Judicial Control of Administrative Action 85 (1965).

15 Barber, supra note 17, at 36; see P. Woll, American Bureaucracy 138-41 (1963).

${ }^{16}$ Cf. Sharp, The Classical American Doctrine of "The Separation of Powers," 2 U. CHI. L. REv. 385 (1935).

17 BARBER, supra note 17 , at 36 .
} 
clause, and the principle of government by representative assemblies thus leads him to confirm his conclusion that the principle of constitutional supremacy is the most satisfactory theoretical foundation for the rule of non-delegation. The arrangement of offices and powers specified by the Constitution is supreme law. The simple expectation in the constituent act of establishing government that this arrangement may not be changed by a temporary majority controlling the powers of government at any given moment provides the touchstone for defining the scope of the rule of non-delegation: "Congress may not substitute its will for the will of the constituent authority by destroying the constitutional arrangement through abdications." 48

\section{B. The Prohibition Against Legislative Abdication}

For Professor Barber, the non-delegation doctrine would prohibit Congress from abdicating its constitutional powers and place upon it a correlative duty to exercise those powers. But what is meant by "abdication"? And what is the nature of Congress" "duty" to exercise its legislative powers?

The "essential act" required of Congress in meeting its constitutional responsibilities, in Professor Barber's view, is "deciding between conflicting proposals presented by clashing interests." 49 If Congress, instead, "deliberately transfers to others the responsibility for decision among what public debate shows to be the most salient policy alternatives presented to it," 50 it has abdicated its constitutional responsibility by failing to exercise its powers. The delegation involved is therefore unconstitutional.

This does not mean, of course, that Congress may never delegate decision-making powers. It means only that the delegation must appear to be a necessary and proper "instrument of decision" rather than a "substitute for decision." If Congress has made a clear policy decision among the salient alternatives presented to it, and if the delegation in question is instrumental to that decision, Congress has exercised its responsibilities rather than evaded them. The delegation involved is therefore constitutional. Indeed, Professor Barber would apply the non-delegation doctrine in a "permissive spirit" ${ }^{2}$ until it became clear that Congress was deliberately evad-

18 Id. at 37.

"Id. at 38.

so Id.

st Id. at 41.

52 Id. at 50. Professor Barber would sustain certain delegations, even if made from "congressional irresolution," if Congress indicated, by a statutory provision for mandatory review 
ing its responsibility for decision.

Several propositions, useful in approaching the task of constitutional adjudication, follow from this analysis. First, the controlling consideration in determining the constitutionality of a delegation of legislative power is the nature of the congressional decision to delegate rather than, for example, the character of the power delegated or the identity of the delegate. ${ }^{53}$ Second, the relative degree of explicitness that may properly be required of statutory standards must be measured by the issues that Congress regarded as salient at the time of the delegation, since the essential function of standards is to "accurately communicate the decision" that Congress actually made from among the policy alternatives it considered. ${ }^{54}$ Third, investigations into the legislative history of particular delegations of power inevitably will become more significant than they presently are because of the need to determine whether the statute expresses a clear choice from among the salient alternatives that were before Congress when it acted or, rather, whether it indicates an abdication of choice. ${ }^{55}$

Professor Barber thus states a complex and interesting theory. It is a theory that seeks to mediate the tensions between the role that delegation to administration must play as "the dynamo of the modern social service state," ${ }^{156}$ and the compelling necessity of preserving the ancient democratic values of responsive, representative government. ${ }^{57}$ The non-delegation doctrine is, of course, the mediating agent between these tensions. By focusing upon the structural norms implicit in the Constitution's architecture, ${ }^{58}$ Professor Barber argues with a refreshing freedom from dogmatic assertion that constitutional authority and stability are the proper conceptual foundations of the doctrine.

and reenactment, that it had committed itself to decide the issues delegated after a period of administrative experience. Id at 123-27; see Cutler \& Johnson, Regulation and the Political Process, 84 YALE L.J. 1395, 1401-02 (1975).

${ }^{53}$ BARBER, supra note 17, at 41, 49; see text and notes at notes 98-122 infra.

" BarBer, supra note 17, at 43; see Merrill, Standards-A Safeguard for the Exercise of Delegated Power, 47 NEB. L. REv. 469 (1968).

${ }^{35}$ Barber, supra note 17, at 43-48; see Alfange, Free Speech and Symbolic Conduct: The Draft-Card Burning Case, 1968 Sup. CT. Rev. 1, 27-38; Alfange, The Relevance of Legislative Facts in Constitutional Law, 114 U. PA. L. Rev. 637 (1966); Ely, Legislative and Administrative Motivation in Constitutional Law, 79 YaLE L.J. 1205 (1970); cf. Fletcher v. Peck, 10 U.S. (6 Cranch) 87 (1810).

${ }^{56}$ L. JAFFE, supra note 10, at 85.

${ }^{57}$ Professor Barber notes that his theory "belongs to a family of norms at the basis of constitutional arguments for the positive state: the supremacy clause, the necessary and proper clause, and the agency theory of the Preamble." Barber, supra note 17, at 50.

ss See C. Black, JR., Structure and Relationship in Constitutional Law (1969). 
This book is published at a time when many commentators have come to believe that the non-delegation doctrine, as traditionally understood and enforced, must be regarded as a failure.$^{59}$ Professor Barber's attempt to justify and rationalize the doctrine not only merits consideration as a thoughtful response to such concerns; it also suggests rewarding areas for further inquiry. Careful examination of one implication of his analysis, the central importance of "institutional competence" in interpreting the constitutional arrangement of offices and powers, serves to illuminate the concept of legislative abdication.

\section{The Significance of Institutional Competence}

It is almost a half-century since the first great scholar of American administrative law, Ernst Freund, ${ }^{60}$ wrote: ${ }^{61}$

While it is extremely difficult to formulate a generally valid principle of legitimacy of delegation, the observation may be hazarded, that with regard to major matters the appropriate sphere of delegated authority is where there are no controverted issues of policy or of opinion. Hence a liberal delegation may be expected, and is actually found, in safety legislation, in which arrangements of a purely technical character necessarily play a conspicuous part. Even here, however, direct statutory regulation may be preferred, if the subject matter touches class interests or otherwise has a strong public appeal . . . .

It is probably true, as Professor Jaffe has written, that Freund's observation is "demonstrably too narrow to describe legislative phenomena or to fulfill political need." 62 But it nevertheless states a major premise: controverted issues of public policy are properly decided, as nearly as effective political and institutional arrange-

31 Professor Davis is perhaps the most important proponent of this position: "The nondelegation doctrine is almost a complete failure. It has not prevented the delegation of legislative power. Nor has it accomplished its later purpose of assuring that delegated power will be guided by meaningful standards. More importantly, it has failed to provide needed protection against unnecessary and uncontrolled discretionary power. The time has come for the courts to acknowledge that the non-delegation doctrine is unsatisfactory and to invent better ways to protect against arbitrary administrative power." K. DAvis, ADMINISTRATIVE LAw Treatise $\$ 2.00$, at 40 (Supp. 1970).

so See Allen, Ernst Freund and the New Age of Legislation, in E. Freund, Standards of American Legislation vii (1965).

" E. Freund, Administrative Powers over Persons and Property 218 (1928). See also Freund, The Substitution of Rule for Discretion in Public Law, 9 AM. Pot. Scr. Rev. 666 (1915).

${ }^{62}$ L. JAFFE, supra note 10 , at 34. 
ments will permit, in forums closest to the sources of popular representation. ${ }^{63}$

Professor Barber's suggestive analysis serves the important contemporary function of providing a full-scale exploration of the values that Freund emphasized as lying at the foundation of the nondelegation doctrine. ${ }^{64}$ Strengthening these values, in my judgment, will require the Supreme Court and administrative law scholars to place greater emphasis than they have in the past upon considerations of institutional competence implicit in the structural premises of the Constitution-upon the capacity of particular institutions of government uniquely to perform certain tasks committed to them by the Constitution.

Professor Barber does not speak directly to the role that institutional competence should play in giving content to the nondelegation doctrine. But his emphasis upon preventing the legislative abdication of constitutional power has direct implications for the development of that role. The significance of considerations of institutional competence in redefining the non-delegation doctrine can perhaps best be demonstrated by examining the relationship of the Congress, the President, and private parties to the exercise of certain constitutional powers.

\section{A. The Congress}

A recent decision of the Supreme Court is particularly instructive in suggesting a basis for a theory of non-delegation of legislative power based upon considerations of institutional competence. The decision is National Cable Television Association v. United States, ${ }^{65}$ a case decided after Professor Barber's book was written.

In that case, a trade association representing community antenna television (CATV) systems, which transmit television programs by cable, challenged a schedule of fees set down by the Fed-

${ }^{63}$ Professor Bickel, in arguing that "the doctrine that delegation without standards is unconstitutional is no mere technical teaching," wrote: "It is concerned with the sources of policy, with the crucial joinder between power and broadly based democratic responsibility, bestowed and discharged after the fashion of representative government. Delegation without standards shortcircuits the lines of responsibility that make the political process meaningful." Bickel, The Constitution and the War, CoMmentary, July 1972, at 49, 52.

a See G. Robinson \& E. Gellhorn, The Administrative Process 749-61 (1974); Wright, Beyond Discretionary Justice, 81 Yale L.J. 575 (1972).

${ }^{65} 415$ U.S. 336 (1974). A related issue was decided according to similar principles in a companion case. FPC v. New England Power Co., 415 U.S. 345 (1974). Justice Marshall, with whom Justice Brennan joined, wrote a separate opinion dissenting in the FCC case and concurring in the result of the FPC case. 415 U.S. at 352. Justices Blackmun and Powell took no part in either decision. 
eral Communications Commission. ${ }^{66}$ The fees were imposed pursuant to a statute which provided: "It is the sense of the Congress that any work, service . . . benefit . . . license . . . or similar thing of value or utility performed, furnished, provided, granted, or issued by any Federal agency . . . to or for any person . . . shall be selfsustaining to the full extent possible, and the head of each Federal agency is authorized by regulation . . . to prescribe therefor such fee, charge, or price, if any, as he shall determine. . . to be fair and equitable taking into consideration direct and indirect cost to the Government, value to the recipient, public policy or interest served, and other pertinent facts . . .."67

The Commission at first established only nominal filing fees, ${ }^{68}$ but under the prodding of Congress it later imposed an annual fee for each cable television system, calculated at the rate of thirty cents for each subscriber to the system. The Commission estimated that fees set at this level would produce an annual revenue equal to the direct and indirect costs of CATV regulation. In short, the fees collected from the industry would reimburse the government for the entire cost of regulating the industry. The Commission regarded the thirty-cents-per-subscriber fee as approximating, in the statutory language, the "value to the recipient" of the federal regulatory effort. ${ }^{69}$

For the Court, the legality of the Commission's schedule turned upon the essential differences between a fee and a tax. A fee, the Court said, is "incident to a voluntary act, e.g., a request that a public agency permit an applicant to practice law or medicine or construct a house or run a broadcast station."70 Congress may authorize an administrative agency to exact a fee for the services it performs in granting such requests, the Court said, because the agency thereby "bestows a benefit on the applicant, not shared by other members of society." "If the statute did no more than permit the Commission to impose fees measured by the "value to the recipient," no serious questions of unconstitutional delegation would be raised.

"The Commission's authority to regulate community antenna television systems had been sustained in an earlier decision. United States v. Southwestern Cable Co., 392 U.S. 157 (1968); see United States v. Midwest Video Corp., 406 U.S. 649 (1972); Cable Television Report \& Order, 36 F.C.C.2d 1 (1972).

${ }^{\circ 7}$ Independent Offices Appropriation Act of 1952, 31 U.S.C. $\S 483 a$ (1970) (emphasis added).

"s See 21 F.C.C.2d 502, 503 (1970); Aeronautical Radio, Inc. v. United States, 335 F.2d 304 (7th Cir. 1964), cert. denied, 379 U.S. 966 (1965).

1" 28 F.C.C.2d 139, 150-51 (1971); 23 F.C.C. 2 d 880, 897-98 (1970).

30415 U.S. at 340.

IId. at 341 . 
But the statute under review went further. It authorized the Commission to consider the "public policy or interest served, and other pertinent facts" in imposing fees. The Court found that this language, "if read literally, carries an agency far from its customary orbit and puts it in search of revenue in the manner of an Appropriations Committee of the House." 72 The implications of such a grant of authority were significant: ${ }^{73}$

The lawmaker may, in light of the "public policy or interest served," make the assessment heavy if the lawmaker wants to discourage the activity; or it may make the levy slight if a bounty is to be bestowed; or the lawmaker may make a substantial levy to keep entrepreneurs from exploiting a semipublic cause for their own personal aggrandizement. Such assessments are in the nature of "taxes" which under our constitutional regime are traditionally levied by Congress.

In short, the statute could be taken as delegating to the Commission the legislative power to levy taxes.

For the Court, this possibility presented a serious constitutional question. After invoking the authority of A.L.A. Schechter Poultry Corp. $v$. United States ${ }^{74}$ the Court decided "to read the Act narrowly to avoid constitutional problems." "75 It held, in an opinion written by Justice Douglas, that because it "would be such a sharp break with our traditions to conclude that Congress had bestowed on a federal agency the taxing power," the statute should be read "narrowly as authorizing not a 'tax' but a 'fee." "76 This construction meant that the phrase "value to the recipient" should be read as the appropriate measure of the Commission's power; the nettlesome language, "public policy or interest served, and other pertinent facts," was hastily dismissed on the doubtful ground that it "would not seem relevant to the present case." 77

Because the fees imposed by the Commission reimbursed the government for all of its direct and indirect costs in regulating community antenna television systems, those who operated such systems were paying not only for whatever special benefits they might receive from federal regulation but also for "the protective services rendered the public by the Commission"78_a result beyond the

\footnotetext{
${ }^{72} I d$. (emphasis in original).

${ }^{73} \mathrm{Id}$. (footnote omitted).

7295 U.S. 495 (1935); see note 2 supra.

75415 U.S. at 342 .

16 Id. at 341 .

"Id. at 343 .

${ }^{78}$ Id. at 341 .
} 
Commission's statutory authority to require under the "value to the recipient" language. For this reason, the Court remanded the case to the Commission to set new fees in light of the narrowed reading of the statutory authorization..$^{79}$

The Court's reliance upon Schechter-long a "disfavored precedent" 10 - to raise constitutional doubts about the literal meaning of the statute was at least questionable. The statutory standards that Congress prescribed for agencies to follow in setting fees were surely as intelligible and definite as those sustained by the Court in many prior decisions ${ }^{81}$ as Justice Marshall's dissenting opinion persuasively argued. ${ }^{82}$ Moreover, the legislative history gave at least some indication that Congress wanted the Commission to adjust its fee structure "to fully support all its activities so the taxpayers will not be required to bear any part of the load in view of the profits regulated by this agency."

By relying upon Schechter to confine the statutory language and avoid a constitutional adjudication that might prove premature or unnecessary, the Court sought to bring the case within the delegation principle and to warn Congress that if it intended to delegate. the power to levy taxes to an administrative agency, it should do so explicitly and with full awareness that such a decision would raise serious constitutional questions.

The manner in which the Court employed the non-delegation doctrine in National Cable Television Association bears a strong similarity to its approach in Kent $v$. Dulles, ${ }^{84}$ a 1958 decision also written by Justice Douglas. The issue in Kent was the validity of regulations promulgated by the Secretary of State pursuant to a general statutory authorization to "grant and issue passports . . . under such rules as the President shall designate and prescribe ...." 85 The regulations required passport applicants to "subscribe, under oath or affirmation, to a statement with respect to present or past membership in the Communist Party." ${ }^{88}$ Kent chal-

" See also Algonquin SNG, Inc. v. Federal Energy Adm'n, 518 F.2d 1051 (D.C. Cir. 1975), cert. granted, 44 U.S.L.W. 3257 (U.S. Nov. 4, 1975).

so Gardner \& Greenberger, Judicial Review of Administrative Action and Responsible Government, 63 Geo. L.J. 7, 33 n.169 (1974); see 1 K. Davis, Administrative Law Treatise $\$$ 2.01 , at 76 (1958).

81 See, e.g., Lichter v. United States, 334 U.S. 742 (1948); Yakus v. United States, 321 U.S. 414, 423-27 (1944); 1 K. Davis, Administrative Law Treatise $\$ 2.03$ (1958).

82415 U.S. at 354.

23 H.R. REp. No. 316, 91st Cong., 1st Sess. 7-8 (1967); H.R. Conf. Rep. No. 649, 91st Cong., 1st Sess. 6 (1969). The passage is quoted by the Court. 415 U.S. at 339.

s 357 U.S. 116 (1958).

${ }^{83} 22$ U.S.C. $\$ 211$ (a) (1970). The Court quotes the relevant sections of the statute in its opinion. 357 U.S. at 123.

st 17 Fed. Reg. 8014 (1952). 
lenged the constitutionality of this requirement. The Court found that it "would be faced with important constitutional questions" 87 if the statute authorized the regulations; by granting the Secretary "authority to withhold passports to citizens because of their beliefs or associations," 88 Congress at least would have approached and might have trenched upon the right to travel guaranteed by the fifth amendment.

As in National Cable Television Association, the Court did not rule on the constitutionality of the substantive requirement in question. Instead, it held as a matter of statutory construction that Congress had not delegated to the Secretary the authority to condition the issuance of passports upon an applicant's beliefs or associations. At least, the Court said, "Congress has made no such provision in explicit terms," practice, was enough to support a narrow reading. Thus, as in National Cable Television Association, the effect of the Court's decision was to avoid deciding the "important constitutional questions" presented; at the same time, the decision created conditions conducive to congressional reconsideration of the substantive requirement in question.

In an important sense, the Court was instructing Congress that making the underlying policy choice to require that passport applicants supply a statement as to their beliefs or associations would invite searching constitutional inquiry. The Court did not tell Congress whether to make that choice, but it did give Congress the opportunity to reconsider the choice with an awareness that an affirmation of the Secretary's policy would implicate fundamental values. As Professor Bickel wrote: ${ }^{80}$

37357 U.S. at 130.

\& The legitimacy of granting the State Department almost unrestricted authority to deny passports had been questioned for at least a generation. See E. Freund, Administrative Powers over Persons and Property 97 (1928).

357 U.S. at 130.

90 A. Bickel, The Least Dangerous Branch 165-66 (1962). Professor Summers, in describing Justice Frankfurter's conception of the judge's function in statutory interpretation, has suggested as well the considerations that may have animated the Court in Kent:

What Frankfurter says is that these values or policies are so basic, so integral a part of our social and legal pattern, that Congress cannot deny or destroy them without thinking. The Court will protect these values at least until Congress has given them the deliberate consideration which is evidenced by explicit statutory words. The Court does not block Congress; it only checks its thoughtlessness.

Summers, Frankfurter, Labor Law and the Judge's Function, 67 YALE L.J. 266, 286 (1957). The question of "remanding to Congress for a second look" is explored in Bickel \& Wellington, Legislative Purpose and the Judicial Process: The Lincoln Mills Case, 71 Harv. L. REv. 1 (1957); Wellington, Machinists $v$. Street: Statutory Interpretation and the Avoidance of Constitutional Issues, 1961 Sup. CT. REv. 49; cf. Freedman, The Uses and Limits of Remand in Administrative Law: Staleness of the Record, 115 U. PA. L. REv. 145 (1966). 
This was remanding to Congress for a second look-not for the necessary initial decision, but for orderly, deliberate, explicit, and formal reconsideration of a decision previously made, but made back-handedly, off-handedly, less explicitly than is desirable with respect to an issue of such grave importance.

By interpreting the statute narrowly, the Court offered Congress the opportunity for a "sober second thought":91 was it necessary or useful or wise to grant the Secretary the authority he thought he possessed if to do so would be to press substantive constitutional questions?

In straining to reach the result it did, the Court in Kent may well have read the prior historical practice erroneously and thereby found a narrower substantive delegation than the record warranted. ${ }^{22} \mathrm{~A}$ more candid reading of the historical practice might have suggested that Congress had clearly expressed a choice between the policy alternatives it faced, and that the Secretary had read that expression accurately.

In commenting upon the decision, Professor Barber argues that because the substantive constitutional issue presented by Congress's action loomed so large in the Court's method of resolution, "the delegation problem was not the majority's real concern." ${ }^{\text {93 }}$ It is true, as Professor Barber states, that the Court's resolution of the issues presented in Kent "did not call for greater specificity of decision or for finer legislative draftsmanship as means of holding the secretary reponsible to congressional policy." ${ }^{94}$ But the non-delegation doctrine can and does properly serve purposes beyond holding congressional delegates responsible to legislative policy. It serves the further purpose, in terms drawn from Professor Barber's analysis, of preventing congressional abdication of responsibility-in this case the responsibility of the legislature in a constitutional system such as ours for presenting ultimate questions of legality to the courts only when searching deliberation and thoughtful exploration of the alternatives has presented none that is accept-

" Stone, The Common Law in the United States, 50 HaRv. L. Rev. 4, 25 (1936); see C. Wyzanski, Whereas-A Judge's Premises 162 (1965); Schwartz, Legal Restriction of Competition in the Regulated Industries: An Abdication of Judicial Responsibility, 67 HARv. L. REv. 436,475 (1954).

12 The Court's reading of the prior historical practice was sharply disputed by the dissenting opinion and elsewhere has been characterized as "fictive." A. BicKEL, supra note 90, at 201 (1962); see Zemel v. Rusk, 381 U.S. 1 (1965); Jaffe, The Right to Travel: The Passport Problem, 35 Foreign Affairs 17, 22-23 (1956); cf. Friendly, Mr. Justice Frankfurter and the Reading of Statutes, in Fruix Frankfurter: The Judge 30, 44 (W. Mendelson ed. 1964).

"3 BARBER, supra note 17, at 98 .

"Id. 
able and of less constitutional moment. In Kent, Congress may have abdicated that responsibility to the extent that it had failed to appreciate or to grapple seriously with the constitutional propriety of granting to the Secretary the power he had presumed. The Court's decision allowed-if it did not indeed require-Congress to reassume that responsibility. The use of the non-delegation doctrine to enforce legislative responsibility in this manner is entirely consistent with Professor Barber's analysis of the functions that the doctrine was intended to serve. ${ }^{95}$ Moreover, it puts at the service of the Court an additional mediating device by which it may perform its awesome responsibility of constitutional adjudication..$^{96}$

The Court's decision in Kent is thus similar to its decision in National Cable Television Association to the extent that it admonishes Congress that when it chooses to delegate legislative power in a manner that suggests "a sharp break with our traditions," it must do so explicitly and as a matter of deliberated choice. But of the two decisions, National Cable Television Association may ultimately prove the more significant for the development of the nondelegation doctrine because of what it implies about the importance of institutional competence.

In Kent the Court began its analysis with the premise that the "right to travel is a part of the 'liberty' of which the citizen cannot be deprived without due process of law under the Fifth Amendment." The Court seemed prepared to assume that Congress could, by more precise draftsmanship, succeed in making clear its intention to delegate to the Secretary of State the authority to withhold passports from citizens because of their beliefs or associations. Such a statute would properly present the question of whether Congress may constitutionally place such restrictions upon a fifth amendment right. If the Court eventually were to hold that Congress may not do so, the decision would rest upon a judgment that the fifth amendment prohibits the federal government from restricting the right to travel in such a manner, regardless of which branch promulgates the restriction. It would not rest upon considerations of the unique institutional competence of any particular branch of government.

The decision in National Cable Television Association, how-

"s Professor Barber may therefore overstate when he concludes that Kent "is not a case - seeking to hold Congress to some conception of its constitutional responsibilities." Id. at 97.

is See Bickel, Foreword: The Passive Virtues, 75 Harv. L. Rev. 40 (1961); Oestereich v. Selective Serv. Sys. Local Bd. No. 11, 393 U.S. 233, 239 (1968) (Harlan, J., concurring); Greene v. McElroy, 360 U.S. 474, 509 (1959) (Harlan, J., concurring specially); Watkins v. United States, 354 U.S. 178 (1957); Garrott v. United States, 340 F.2d 615 (Ct. Cl. 1965).

${ }^{97} 357$ U.S. at 125. 
ever, does seem to address the question of institutional competence in a way that Kent does not. By stressing that "[t]axation is a legislative function" and that, under the Constitution, Congress "is the sole organ for levying taxes," to hold Congress to more than merely the responsibility of presenting constitutional questions only after careful and conscious deliberation. The Court may have been seeking as well to hold Congress to the different but equally fundamental responsibility of exercising the constitutional power to impose taxes itself.

What is the basis in theory for such a responsibility? The power to tax is surely one of the most important of the legislative powers created by the Constitution. In the history of other nations, as the Framers had good reason to know, the power to tax had proven strikingly susceptible to oppressive application and abuse. "[T]he power to tax," as Chief Justice Marshall observed in McCulloch $v$. Maryland, "involves the power to destroy." ation without representation was a part of the Framers' revolutionary heritage, ${ }^{100}$ affording them particular cause to construct protections against the possibility that such a momentous power might come to be exercised by small numbers of men in dark ministries. The decision of the Framers to place the power to impose taxes in the legislative branch of the government was a response to these considerations. ${ }^{101}$

Congress is the national institution that takes its character most directly from the political responsiveness of its members. In addition, senators and representatives, elected and subject to reelection by states or local constituencies, constitute a legislative institution of broad-based diversity. These characteristics serve to define the unique institutional competence of Congress for purposes of levying taxes. As Chief Justice Marshall went on to declare in McCulloch: "The only security against the abuse of this power, is found in the structure of the government itself. In imposing a tax, the legislature acts upon its constituents. This is, in general, a suffi-

9s 415 U.S. at 340.

" 17 U.S. (4 Wheat.) 316, 431 (1819). The Court in National Cable Television Association quoted Justice Holmes's rejoinder: "The power to tax is not the power to destroy while this Court sits." 415 U.S. 341 n.4.

100 See J. Alden, The American Revolution, 1775-1783, at 216 (1954); B. Bailyn, The Ordeal of Thomas Hutchinson 73-74, 90 (1974); B. Bailyn, The Origins of American Politics 159 (1968); S. Morison, The Oxford History of the American People 181-209 (1965); cf. B. Ballyn, The Ideological Origins of the American Revolution 162 (1967).

10i This may explain, too, why the Constitution, in an unusually explicit provision, requires that "[a]ll bills for raising Revenue shall originate in the House of Representatives," the most broadly representative of our legislative institutions. U.S. CoNST. art. I, $\S 7$. 
cient security against erroneous and oppressive taxation." 102

Because no other institution of the federal government except Congress possesses the unique characteristics that the Framers relied upon to provide citizens with an institutional security against unfair or oppressive taxation, no mere delegate of Congress could aspire to exercise the power to tax in a manner qualitatively similar to Congress. The Court in National Cable Television Association, familiar with the Framers' design, may have been suggesting, therefore, that considerations of institutional competence would prevent Congress from constitutionally delegating the power to impose taxes to anyone and at all.

As a more general matter, this reading of National Cable Television Association suggests that the Court may believe that legislative powers are not equivalent in their constitutional significance, and that the particular significance of any specific power has implications for the freedom of Congress constitutionally to delegate its exercise to others. This proposition would mean that the Constitution finally should be read to prohibit Congress from delegating certain powers no matter how clearly it proposes to speak to the policy issues involved. With respect to each of these powers the act of delegation itself would be an abdication of one of Congress' constitutional responsibilities.

How, then, does one determine whether a particular legislative power is one that Congress may not delegate? The answer must lie in the nature of the particular power involved and the intended relationship of that power to the structure of our constitutional scheme. ${ }^{103}$

Consider, for example, the power of Congress to impeach and convict a President for "Treason, Bribery, or other high Crimes and Misdemeanors." 104 It was because of the extraordinary character of the charges warranting impeachment that the Framers of the Constitution assigned the function to Congress-the House to accuse and the Senate to try-rather than to the Supreme Court. The Framers regarded the institution of impeachment as "preeminently a political process, likely to agitate the passions of the whole community." 105 It was, as Hamilton wrote in The Federalist, "a method of NATIONAL INQUEST into the conduct of public men," best assigned

10217 U.S. (4 Wheat.) 316,428 (1819).

100 See generally C. Black, JR., Structure and Relationship in Constitutional LaW (1969).

104 U.S. Const. art. II, § 4. See generally R. Berger, IMPEACHMEnT: The Constitutional Problems (1973); Pollak, The Constitution as an Experiment, 123 U. PA. L. REv. 1318 (1975).

ios A. Schlesinger, Jr., The Imperial Presidency 11 (1973). 
to "the representatives of the nation themselves." 108 Only the Senate, in Hamilton's view, "would possess the degree of credit and authority, which might, on certain occasions, be indispensable towards reconciling the people to a decision" one way or the other. ${ }^{107}$ And he added another significant consideration: "The awful discretion which a court of impeachments must necessarily have, to doom to honor or to infamy the most confidential and the most distinguished characters of the community, forbids the commitment of the trust to a small number of persons." 108

The decision of the Framers to vest in Congress the momentous power of impeaching the President thus reflects a single judgment about the intimate relationship between the nature of the offense and the character of the tribunal. The arguments that Hamilton adduced to support the designation of Congress as the nation's impeachment tribunal indicate that the Framers believed that only a body politically responsive in the unique manner of Congress could bring the desired qualities of judgment and lend the desired lineaments of legitimacy to the uniquely political questions presented by an impeachment proceeding. The Framers' choice of Congress was thus governed significantly by considerations of institutional competence. If Congress may not delegate the power to impeach, then, it must be because no delegate, however conscientious or honorable, could replicate the qualitative dimensions of judgment that the Framers believed Congress uniquely would bring to the determination of impeachment proceedings. ${ }^{100}$

There is an additional reason for concluding that any delegation of the impeachment power would be an abdication of Congress's constitutional responsibilities. As Hamilton wrote in The Federalist, impeachment proceedings in their nature could "never be tied down by such strict rules, either in the delineation of the offence by the prosecutors, or in the construction of it by the judges, as in common cases serve to limit the discretion of courts." 110 Hamil-

ion The Federalist No. 65, at 427 (B. Wright ed. 1961) (A. Hamilton).

107 Id.

105 Id. at 428. See also The Federalist No. 66, at 431 (B. Wright ed. 1961) (A. Hamilton).

100 The principle requiring Congress to exercise rather than delegate certain of its constitutional responsibilities obviously must be accomodated at many points to the "necessary and proper" clause. Thus, although Congress may not delegate its power to levy taxes, it may delegate to an administrative agency the power to collect taxes. The necessary and proper clause and the non-delegation doctrine will not always be entirely incompatible: even when the Framers have determined that Congress may not delegate its power to decide a particular matter, they may nonetheless have permitted Congress to exercise its discretion to determine if it needs assistance in implementing its decision.

110 The Federalist No. 65, at 428 (B. Wright ed. 1961) (A. Hamilton); see R. Berger, Impeachment: The Constitutional Problems 53-102 (1973). 
ton's statement suggests the Framers' perception that the task of exercising judgment in an impeachment proceeding could not be principled in the usual sense. The considerations that the Framers understood would govern Congress's performance of the task, whatever they might be, would not be susceptible to formulation into directory standards of the kind that Congress would traditionally seek to provide when it delegated legislative power.

When a constitutionally-assigned power is by its nature peculiarly resistant to the formulation of governing principles and standards, the indications become strong that the Framers placed a deep reliance for its proper exercise upon the unique qualities-the institutional competence-of the body to which it was assigned. If Congress may not delegate the power to impeach, it must be for the further and independent reason that it is one of these powers. ${ }^{111}$

Thus, there are at least two classes of cases in which application of a revived non-delegation doctrine based upon considerations of institutional competence will have important consequences. The first class, represented by Kent $v$. Dulles, involves cases in which the legislature seeks to delegate a power that may be delegated constitutionally only under certain conditions. For the delegation to be constitutional, it must be an "instrument of decision" rather than a "substitute for decision," in Professor Barber's terms, and the statutory standards and legislative history accompanying it must accurately communicate the decision that Congress actually made from among the salient policy alternatives that it considered. ${ }^{112}$

The Supreme Court has usually invoked the delegation doctrine in cases of this kind when Congress has delegated power in such a manner as to threaten the invasion of personal constitutional rights. But there is no reason to limit application of the doctrine only to such cases. Congress should be required to meet-rather than be permitted to evade-its responsibility to make basic policy decisions before delegating legislative power, whether or not individual constitutional rights are involved.

The second class of cases, represented by National Cable Television Association $v$. United States, involves instances in which the legislature seeks to delegate a power that may not be delegated, even though the legislature itself may exercise the power constitu-

III Among other legislative powers to which the same analysis may apply is the following: "Each House shall be the Judge of the Elections, Returns and Qualifications of its own Members . . . ." U.S. Const. art. I, § 5; see Powell v. McCormack, 395 U.S. 486 (1969).

112 When legislative power is delegated to a private party, a third condition will obtain: the private party must be disinterested and sufficiently expert. See text at notes 133-38 infra. 
tionally. The powers of Congress to levy taxes and to impeach the President are of this character. ${ }^{13}$

In determining whether a particular legislative power falls within this second class, the Supreme Court must ask whether the structural premises of the Constitution indicate that the Framers intended to vest the power in an institution uniquely competent to exercise it. The Court must further ask whether the power by its nature is peculiarly resistant to the formulation of governing standards for its exercise. When powers of this character are involved, the Court should hold that Congress cannot constitutionally achieve their delegation because the act would be an abdication of Congress's constitutional responsibility for decision.

\section{B. The President}

The possibility that certain constitutionally-assigned powers may not be delegated is raised only once in The Federalist, but the context is revealing for purposes of this analysis. Hamilton, in discussing the power of the President "to grant Reprieves and Pardons for Offenses against the United States," "14 writes that "it is questionable, whether, in a limited Constitution, that power could be delegated by law . . . ."115 What is there about the unique competence of the President to perform the task of granting pardons and reprieves that casts doubt on the permissibility of its delegation?

Hamilton's principal argument for placing the power to grant pardons in the President is his special capacity for taking prompt action, particularly by comparison to Congress. Prompt action is especially to be desired, Hamilton writes, "in seasons of insurrection or rebellion . . . when a well-timed offer of pardon to the insurgents

"13 These two general classes will not, of course, embrace all possible cases. There will be some cases in which the Framers' intentions are not wholly clear, yet the desirability of requiring exercise of the power in question by an institution of unique competence seems great. These may be cases in which judicial insistence upon a demonstration that the delegation is an "instrument of decision" and upon the traditional requirement of meaningful standards may be particularly necessary. These cases, in short, call for a sensitive exercise of judicial discrimination. As Learned Hand once wrote, "So much of what we do is not a case of barbara celarent anyway; but of more or less." Letter from Learned Hand to Felix Frankfurter, March 30, 1949 (The Felix Frankfurter Papers, Library of Congress), quoted in Atkinson, Justice Sherman Minton and the Balance of Liberty, 50 IND. L.J. 34, 59 (1974).

II' U.S. ConsT. art. I, § 5; see Schick v. Reed, 419 U.S. 256 (1974); Biddle v. Perovich, 274 U.S. 480 (1927); Ex parte Grossman, 267 U.S. 87 (1925); Ex parte Garland, 71 U.S. (4 Wall.) 333 (1866); Ex parte Wells, 59 U.S. (18 How.) 307 (1856); United States v. Wilson, 32 U.S. (7 Pet.) 150 (1833); E. Corwin, The President: Office and Powers 158-68 (4th rev. ed. 1957); W. Humbert, The Pardoning Power of the President (1941).

115 The Federalist No. 74, at 475 (B. Wright ed. 1961) (A. Hamilton). See generally Note, Executive Clemency in Capital Cases, 39 N.Y.U.L. REv. 136 (1964). 
or rebels may restore the tranquility of the commonwealth." 116 The loss of time that would result if Congress had to be convened "for the purpose of obtaining its sanction to the measure, would frequently be the occasion of letting slip the golden opportunity," perhaps forever. ${ }^{117}$

To this argument he adds a further point:

As the sense of responsibility is always strongest, in proportion as it is undivided, it may be inferred that a single man would be most ready to attend to the force of those motives which might plead for a mitigation of the rigor of the law, and least apt to yield to considerations which were calculated to shelter a fit object of its vengeance. The reflection that the fate of a fellow-creature depended on his sole fiat, would naturally inspire scrupulousness and caution; the dread of being accused of weakness or connivance, would beget equal circumspection, though of a different kind. ${ }^{118}$

Hamilton believed that vesting the power to pardon in the Congress, on the other hand, could lead to untoward consequences. Because "men generally derive confidence from their numbers," legislators if they were granted the power to pardon "might often encourage each other in an act of obduracy, and might be less sensible to the apprehension of suspicion or censure for an injudicious or affected clemency." 119

Hamilton's arguments forcefully support the wisdom of placing the power to pardon in a single individual. But they do not provide a rationale for reading the Constitution to restrict the President's authority to delegate that power to another. Yet the reasons that caused the Framers to select the President as the single individual with whom to entrust the "benign prerogative of mercy" 120 must reflect some sense that only a person accountable to history and to the nation's traditions in the unique manner of the President could bring the desired qualities of moral strength and vision to the performance of the function. ${ }^{121}$ James D. Barber has noted that the

116 The Federalist No. 74, at 475 (B. Wright ed. 1961) (A. Hamilton); see Murphy v. Ford, 390 F. Supp. 1372 (W.D. Mich. 1975).

i17 The Federaust No. 74, at 475 (B. Wright ed. 1961) (A. Hamilton); see 2 The RecordS of the Federal Convention of 1787, at 419 (M. Farrand ed. 1911).

113 The Federalist No. 74, at 473-74 (B. Wright ed. 1961) (A. Hamilton) (emphasis in original).

119 The Federalist No. 74, at 474 (B. Wright ed. 1961) (A. Hamilton).

120 Ex parte Garland, 71 U.S. (4 Wall.) 333, 380 (1866).

121 See Note, The Conditional Presidential Pardon, 28 Stan. L. Rev. 149, 164 (1975). 
President "is expected to personify our betterness in an inspiring way, to express in what he does and is (not just in what he says) a moral idealism which, in much of the public mind, is the very opposite of 'politics.' "122

If this is true, then the argument that the President ought not be permitted to delegate the power to pardon to another-not even to one of Learned Hand's "twenty bishops"123_-becomes persuasive. No other individual, however morally qualified he may appear, can ever be subject to the sobering historical forces that play upon the President and produce the special qualities of judgment that the Framers sought in selecting him as the one person who would exercise the power to pardon in the name of the nation. These qualities of judgment, representing a particular responsiveness to what is truest and best in the national character, may properly be considered a part of the institutional competence of the President.

\section{Private Parties}

The Supreme Court has yet to state a satisfactory theory of the principles governing the delegation of power to private parties. ${ }^{124}$ In a series of decisions extending over almost a century, the Court has found some delegations to private parties constitutional ${ }^{125}$ and others unconstitutional, ${ }^{26}$ without enunciating persuasive reasons for differentiating the two lines of decision. The uncertain state of the law affords an opportunity to formulate a theory of delegation of legislative power to private parties that is consistent with a general theory of delegation and gives appropriate emphasis to considera-

122 J. Barber, The Presidential Character 9 (1972). See generally M. NovaK, Choosing OUR KING (1974).

${ }^{123}$ Hotchkiss v. National City Bank, 200 F. 287, 293 (S.D.N.Y. 1911), aff'd, 201 F. 664 (2d Cir. 1912), aff'd, 231 U.S. 50 (1913).

124 See 1 K. Davis, Administrative Law Treatise § 2.14, at 138 (1958). Several scholars, however, have made significant efforts toward framing a coherent theory. See, e.g., Hale, Our Equivocal Constitutional Guarantees, 39 CoLum. L. Rev. 563 (1939); Jaffe, Law Making by Private Groups, 51 Harv. L. Rev. 201 (1937); Liebmann, Delegation to Private Parties in American Constitutional Law, 50 Ind. L. Rev. 650 (1975); McBain, Law-Making by Property Owners, 36. Pol. Scr. Q. 617 (1921); Wirtz, Government by Private Groups, 13 LA. L. Rev. 440 (1953); Note, The State Courts and Delegation of Public Authority to Private Groups, 67 HaRv. L. REv. 1398 (1954). A provocative collection of contemporary materials appears in H. Linde \& G. Bunn, Legislative and Administrative Processes 564-86 (1976).

125 Parker v. Brown, 317 U.S. 341 (1943); Sunshine Anthracite Coal Co. v. Adkins, 310 U.S. 381 (1940); United States v. Rock Royal Co-operative, Inc., 308 U.S. 533 (1939); Currin v. Wallace, 306 U.S. 1 (1939); Thomas Cusack Co. v. Chicago, 242 U.S. 526 (1917); St. Louis, I. Mt. \& S. Ry. v. Taylor, 210 U.S. 281 (1908); Jackson v. Roby, 109 U.S. 440 (1883); see United States v. Mazurie, 419 U.S. 544 (1975).

124 Carter v. Carter Coal Co., 298 U.S. 238 (1936); Washington ex rel. Seattle Titie Trust Co. v. Roberge, 278 U.S. 116 (1928); Eubank v. City of Richmond, 226 U.S. 137 (1912). 
tions of institutional competence.

Delegation to private parties presents one of the rare instances in which Professor Barber's analysis falters. He asserts that "from the logic of the delegation doctrine alone, if Congress delegates as an instrument of decision, the delegation is constitutional regardless of the agent's status." 127 For him, "the question of who receives delegated power is irrelevant," as is "the fitness of the recipient to exercise power." 128 The only relevant question is whether Congress has met, rather than abdicated, its responsibility for choice. The answer to that question in any particular case does not turn upon the identity of the delegate: "Congress may delegate to any agency, public or private, administrative, judicial, or whatever, as long as its delegations are pursuant to choice among salient alternatives."129

Professor Barber elaborates his position by reference to Carter v. Carter Coal Co., ${ }^{130}$ a leading Supreme Court decision. The Court there held that certain sections of the Bituminous Conservation Act of 1935 were unconstitutional because they permitted groups of private producers and miners to fix maximum hours and minimum wages. Because the statute "conferred upon the majority . . . the power to regulate the affairs of an unwilling minority," the Court found that it was "legislative delegation in its most obnoxious form; for it is not even delegation to an official or an official body, presumptively disinterested, but to private persons whose interests may be and often are adverse to the interests of others in the same business." 131

Professor Barber regards as misguided the Court's emphasis in Carter upon the character of the delegate rather than the quality of the legislative decision-making process. ${ }^{132}$ Yet the Court's language in Carter suggests its recurrent concern with the question of whether private persons, even though they have been selected by Congress, ${ }^{133}$

127 BARBER, supra note 17 , at 95 .

128 Id. at 49.

128 Id.

130298 U.S. 238 (1936).

131 Id. at 311; see R. Jackson, The Struggle for Judicial Supremacy 153-65 (1941).

${ }^{132}$ After reciting the Court's argument in the Carter case, Professor Barber states that "the application of our criteria need not have had the same result." BARBER, supra note 17, at 95. He then adds: "Certainly, we can disagree with the possible suggestion that a given delegation is less objectionable depending on the agent's status." Id. at 95.

${ }_{133}$ It could be argued that Congress is most likely to evade its constitutional responsibilities when pressure from private groups is greatest, particularly when the groups are economically or socially powerful. Delegations to private parties would then appear as one class of statutory enactments that should make courts sensitive to the possibility that, in Professor Barber's term, an "abdication" of congressional responsibility may have occurred. Compare Rice v. Foster, 4 Del. (4 Harr.) 479 (1847), with James v. Valtierra, 402 U.S. 137 (1971). 
can be relied upon to exercise the sovereign power of the nation with a disinterestedness sufficient to assure that the interests of all of those subject to regulation will receive fair consideration-consideration of at least the quality and fairness they would receive in a politically accountable legislative forum. Congress abdicates its constitutional responsibility when it delegates decisionmaking authority to a private party lacking the capacity for such disinterested policy making.

In a nation as large and diverse as the United States, regulation if it is to be effective must depend upon a degree of voluntary cooperation between the government and those whose conduct is to be regulated. Delegations to private parties are often a useful means of securing and structuring that cooperation. Recognizing this fact, the Supreme Court has prudently refrained from regarding all such delegations as constitutionally suspect. Rather, it has proceeded on the sensible premise that delegations to private parties are constitutional when they serve important public purposes and give promise of adequately considering and protecting the interests of all of those subject to regulation-including, most particularly, minority groups.

For example, courts commonly have sustained delegations to private parties in the form of statutes that attach public consequences to decisions that the delegate has made or would be making in any event for purposes quite independent of giving content to the legislation. Typical of such statutes are those prohibiting the sale of all drugs except those recognized by the United States Pharmacopoeia and similar pharmaceutical publications. In these cases, the private party's decision to include or exclude a particular drug is invariably made according to pre-existing professional standards in order to serve a particular professional need, rather than as a response to the legislation that gives such decisions a coincidental public effect. ${ }^{134}$ Delegations of this kind carry considerable assurance that the private party's action will be guided not by selfinterest but rather by extrinsic standards, usually formulated and endorsed by a professional community, designed to serve a larger social interest.

By contrast, delegations of legislative power to private parties have most commonly been held unconstitutional when the private party's "self-interest might tend to color its determination,"135 so

13 See, e.g., State v. Wakeen, 263 Wis. 401, 57 N.W.2d 364 (1953); Liebmann, Delegation to Private Parties in American Constitutional Law, 50 IND. L. REv. 650, 680-83 (1975); cf. R.H. Johnson \& Co. v. SEC, 198 F.2d 690 (2d Cir.), cert. denied, 344 U.S. 855 (1952).

t3s Group Health Ins. v. Howell, 40 N.J. 436, 447, 193 A.2d 103, 109 (1963), supplemented, 
that a majority of the private group may come to exercise the delegated power in a manner likely to advance its own (usually economic) interests at the expense of an unwilling minority. ${ }^{136}$ Such delegations deprive affected individuals of the special quality of decision-making integrity promised by the legislative process, ${ }^{137} \mathrm{a}$ consequence that may be objectionable on due process grounds as well. ${ }^{138}$

The doctrine of delegation of legislative power to private parties thus rests upon fundamental concerns for the character of the delegate and for the nature of the decision Congress has committed to the delegate. These concerns reflect considerations similar to those that govern the constitutionality of congressional delegations of legislative power to the President, a circumstance that provides an instructive analogy.

One of the reasons that delegations of legislative power to the President are so often sustained undoubtedly relates to a recognition of his special character as a delegate. He is a public official, sworn to uphold the Constitution and laws of the United States, constrained to public spiritedness by the nation's traditions and history's certain judgment, and within the reach of a number of political and finally electoral processes. Rarely are private parties exercising delegated legislative power circumscribed by such profound imperatives.

In addition, many of the Supreme Court's decisions sustaining particular delegations of legislative power to the President have clearly reflected a judgment about his institutional competence or expertise in specific areas of governance. Thus, the Court's decisions in The Brig Aurora ${ }^{139}$ upholding the delegation to the President of

43 N.J. 104, 202 A.2d 689 (1964). See also State Bd. of Dry Cleaners v. Thrift-D-Lux Cleaners, 40 Cal. 2d 436, 254 P.2d 29 (1953); Allen v. California Bd. of Barber Examiners, 25 Cal. App. 3d 1014, 102 Cal. Rptr. 368 (1972); Chapel v. Commonwealth, 197 Va. 406, 89 S.E.2d 337 (1955).

138 Carter v. Carter Coal Co., 298 U.S. 238 (1936); Eubank v. City of Richmond, 226 U.S. 137 (1912); Remington Arms Co. v. G.E.M. of St. Louis, Inc., 257 Minn. 562, 102 N.W.2d 528 (1960); cf. Gibson v. Berryhill, 411 U.S. 564 (1973); Lathrop v. Donohue, 367 U.S. 820, 878 (1960) (Douglas, J., dissenting).

is7 State v. Allstate Ins. Co., 231 Miss. 869, 97 So. 2d 372 (1957).

iss See Berryhill v. Gibson, 331 F. Supp. 122 (M.D. Ala. 1971), vacated and remanded on other grounds, 411 U.S. 564 (1973); E. Gellhorn, Administrative LaW and Process in a Nutshell 22-23 (1972); L. Jaffe \& N. Nathanson, Administrative Law, Cases and Materials 81 (3d ed. 1968); Jaffe, Law Making by Private Groups, 51 Harv. L. Rev. 201 (1937); cf. McGautha v. California, 402 U.S. 183, 272 nn.21-22 (1971) (Brennan, J., dissenting).

${ }^{39} 11$ U.S. (7 Cranch) 382 (1813); see L. JAFFE, supra note 10, at 56 (1965); H. PRITCHETT, The American Constrtution 200 (1968). Professor Barber discusses both The Brig Aurora and Field v. Clark. BARBER, supra note 17, at 58-63. 
the power to revive the Embargo Act and in Field v. Clark ${ }^{140}$ upholding the delegation to the President of the power to impose retaliatory tariffs upon foreign nations represent a recognition of his unique authority and position in the conduct of foreign affairs. ${ }^{141} \mathrm{~A}$ number of other Supreme Court decisions, particularly those sustaining the war-time delegation of powers to the President, are consistent with a recognition of the wisdom of granting to the one person who is the nation's commander-in-chief a wide executory flexibility in times of national exigency. ${ }^{142}$ Private parties, on the other hand, often do not possess a similar, if not unique, competence to exercise the particular legislative powers delegated to them.

The doctrine of delegation of legislative power to private parties thus searches the fundamental question of institutional competence to perform a governmental task. The doctrine's special role is to determine whether a particular delegate is competent to perform the specific task delegated to him. That determination must take account of the fact that there is a crucial nexus between the nature of the particular legislative power being delegated and the character of the private party chosen to exercise it. The relative degree of disinterestedness that the delegate can be expected to bring to the task of decision and his relative degree of expertness in performing the task are significant criteria for estimating the institutional competence, in a constitutional sense, of a private party to whom Congress has delegated legislative power.

\section{CONCLUSION}

Although the non-delegation doctrine may founder in a "current desuetude," 143 as Professor Barber concedes, the decision in National Cable Television Association v. United States suggests that the Supreme Court may yet revive the doctrine. ${ }^{144}$ But any act (1892).

14143 U.S. 649 (1892); see F. Taussig, The Tariff History of the United States 283

14 See also J.W. Hampton, Jr. \& Co. v. United States, 276 U.S. 394 (1928). For the reasons developed in the text, it is difficult to accede to Professor Barber's apparent view that delegations of power that have been sustained when they were made to the President should also be sustained when made to a private party, so long as Congress has clearly indicated a policy choice among the salient alternatives that were before it.

142 See, e.g., Lichter v. United States, 334 U.S. 742 (1948); Bowles v. Willingham, 321 U.S. 503 (1944); Yakus v. United States, 321 U.S. 414 (1944); United States v. Curtiss-Wright Export Corp., 299 U.S. 304 (1936); United States v. Yoshida Int'l, Inc., 526 F.2d 560 (C.C.P.A. 1975); cf. E. CoRwIN, supra note 114, at 234-42; Freedman, Summary Action by Administrative Agencies, 40 U. CHI. L. REv. 1, 9-11 (1972).

i13 BARBer, supra note 17 , at 24.

it Several Justices of the Supreme Court have occasionally expressed their belief in the 
of resuscitation must go beyond merely reiterating the doctrine's traditional teaching that Congress must state meaningful statutory standards for the exercise of delegated legislative power.

The new lines of the doctrine ought to be drawn to reflect the normative premises underlying Professor Barber's argument that Congress, in the act of delegating legislative power, may not abdicate its constitutional responsibility for choice from among the salient policy alternatives presented to it. This prescription would give meaning to Ernst Freund's enduring counsel that a principal office of the non-delegation doctrine is to ensure that controverted issues of policy and opinion be resolved, as nearly as effective political and institutional arrangements will permit, by those who draw their special character from a representative relationship to the people.

Whenever a court concludes that the Framers regarded the proper exercise of a specific legislative power as closely dependent upon the unique institutional competence of Congress, the non-delegation doctrine would prohibit Congress from delegating that power to another. In these circumstances, the act of delegation would so alter the manner of the power's exercise that the resulting arrangement would no longer be compatible with the Framers' reasons for vesting the power in an institution whose character and nature are defined in the special ways-of political responsiveness and broad-based diversity-that those of Congress are. The informing principle of institutional competence as a guide to the constitutionality of the delegation of legislative power thus focuses on the tension between the nature of the particular power delegated and the character of the particular institution chosen to exercise it.

A reconstruction of the non-delegation doctrine along these lines would then reflect a heightened awareness of considerations of institutional competence implicit in the structural premises of the Constitution itself-of the capacity of particular institutions of government uniquely to perform certain tasks committed to them by the Framers.

vitality of the doctrine. See United States v. Robel, 389 U.S. 258, 272-73 (1967) (Brennan, J., concurring); Arizona v. California, 373 U.S. 546, 626 (1963) (Harlan, J., with Stewart and Douglas, JJ., dissenting). 